\title{
Iron chelation may harm patients with COVID-19
}

\author{
Michael D. Garrick ${ }^{1,2}$ (D) Andrew J. Ghio ${ }^{3}$
}

Received: 10 July 2020 / Accepted: 27 August 2020 / Published online: 1 September 2020

(C) Springer-Verlag GmbH Germany, part of Springer Nature 2020

\section{Dear Editor}

Abobaker's well-intended proposal that iron chelators could improve clinical outcomes for COVID-19 patients [1] is likely to lead to undesired, injurious outcomes. The author bases the proposed therapy on the misunderstanding that COVID-19 leads to a breakdown of hemoglobin into globin, iron, and porphyrin based on using published RNA sequencing of SARS-CoV-2 [2]. The latter investigation identified the viral proteins and modeled their 3-D structure, predicting which polypeptides might target hemoglobin accounting for pathology. It is inferred that iron released from the direct interaction between SARS-CoV-2 and hemoglobin leads to pulmonary damage via reactive oxygen species, citing our prior analysis for this relationship [3] as well as observations of elevated serum ferritin concentrations with COVID-19 [4].

The pathophysiological pathway proposed is initiated by a modest drop in hemoglobin level in COVID-19 patients [4] where standard, well-supported explanations have not been acknowledged [1,2]. All infections induce inflammation which increases the master iron regulator, hepcidin, to induce anemia (i.e., anemia of inflammation (AI)) [5]. AI ordinarily involves competition between host and invader for iron, a nutrient required by the microbe for survival and replication. The host's sequestration of its own iron is a critical part of innate immunity. Accordingly, AI following infection can explain observations of decreased hemoglobin in COVID-19 patients. Moreover, the coronavirus is an RNA virus with its replication relying on a RNA duplex intermediate. Such viruses do not need iron to replicate their genome unlike DNA or retroviruses so iron withholding could be

Michael D. Garrick

mgarrick@buffalo.edu

1 Department of Biochemistry, Jacobs School of Medicine and Biomedical Sciences, University at Buffalo, Buffalo, NY, USA

2 Department of Pediatrics, Jacobs School of Medicine and Biomedical Sciences, University at Buffalo, Buffalo, NY, USA

3 US Environmental Protection Agency, Chapel Hill, NC, USA counterproductive and part of the "cytokine storm" that might be exacerbated by Abobaker's proposed use of iron chelation. Docking models employed to explain hemoglobin loss are predictive of binding only and are unnecessary if hypoferremia in response to $\mathrm{AI}$ is the real cause. One needs to determine the $K_{\mathrm{d}}$ for binding to learn if the viral proteins can actually outcompete hemoglobin ligands that already have high affinity for some of the target regions. Therefore, the proposal that hemoglobin drops due to an interaction with viral proteins may have confused observations on a clinical hemoglobin measurement that reflects red cell numbers after iron withholding with molecular turnover of the globin tetramer within those cells. Elevated serum ferritin in these patients, comparable to the decreased hemoglobin, reflects inflammation associated with infection and this is supported by more frequently elevated acute phase reactants such as $\mathrm{C}$ reactive protein [4]. The classical Hippocratic dictum "primum nil nocere," that is "do no harm," implies here that chelation should not be employed until there is evidence that elevated iron levels exist and are relevant. Before moving in that direction, it must be determined whether COVID-19 leads to elevated iron levels or AI. Useful approaches could include a test that distinguishes whether elevated serum ferritin relates to elevated iron or AI [6] and interrogating whether this new RNA virus has any iron-dependencies. Results could lead to hepcidin antagonists as supportive treatment instead of iron chelation.

Authors' contributions Not applicable.

Funding MDG's research is supported by a grant from the US NIH (grant R01DK109717).

Availability of data and material Not applicable.

\section{Compliance with ethical standards}

Conflict of interest The authors declare that they have no conflict of interest.

Ethics approval Not applicable. 
Consent to participate Not applicable.

Consent for publication Not applicable.

Code availability Not applicable.

\section{References}

1. Abobaker A (2020) Can iron chelation as an adjunct treatment of COVID-19 improve the clinical outcome? Eur J Clin Pharmacol. https://doi.org/10.1007/s00228-020-02942-9

2. Liu W, Li H (2020) COVID-19:Attacks the 1-beta chain of hemoglobin and captures the porphyrin to inhibit human heme metabolism. Available from: https://chemrxivorg/articles/COVID19_Disease_ORF8_and_Surface_Glycoprotein_Inhibit_Heme_Metabolism_by_Binding_to_Porphyrin/11938173 Äccessed 7 Apr 2020. https://doi.org/10.26434/chemrxiv.11938173.v8
3. Turi JL, Yang FM, Garrick MD, Piantadosi CA, Ghio AJ (2004) The iron cycle and oxidative stress in the lung. Free Radic Biol Med 36(7):850-857

4. Chen N, Zhou M, Dong X, Qu J, Gong F, Han Y, Qiu Y, Wang J, Liu Y, Wei Y, Xia Ja YT, Zhang X, Zhang L (2020) Epidemiological and clinical characteristics of 99 cases of 2019 novel coronavirus pneumonia in Wuhan, China: a descriptive study. Lancet 395(10223):507-513. https://doi.org/10.1016/S0140-6736(20) 30211-7

5. Ganz T (2019) Anemia of inflammation. N Engl J Med 381(12): 1148-1157. https://doi.org/10.1056/NEJMra1804281

6. Herbert V, Jayatilleke E, Shaw S, Rosman AS, Giardina P, Grady RW, Bowman B, Gunter EW (1997) Serum ferritin iron, a new test, measures human body iron stores unconfounded by inflammation. Stem Cells 15(4):291-296. https:// doi.org/10.1002/stem.150291

Publisher's note Springer Nature remains neutral with regard to jurisdictional claims in published maps and institutional affiliations. 